\title{
AGE OF THE FLÁAJÖKULL MORAINE RIDGES (SE ICELAND). CRITICAL APPROACH TO USE OF LICHENOMETRY*
}

\section{INTRODUCTION}

The aim of the article is to review the previous datings of the Fláajökull moraines and compare them with the new lichenometric data. To obtain possibly best results several data sources were used, such as glaciological measurements, a map based on aerial photographs taken in 1946, aerial photographs from 1989, historical data, and information concerning neighbourhood glaciers.

The Fláajökull glacier flows south out of the Vatnajökull ice-cap, and its marginal zone attains the level of the ocean coast platform at about $50 \mathrm{~m}$ a.s.l. (Dąbski, Fabiszewski, Pękalska, 1998, Smolska, Szwarczewski, Giriat, Borkowski, 1998). The eastern lobe of the glacier created easily discernible moraine ridges - Fig 1 . The moraines border to the west with moraines of the Heinabergsjökull and the Skalafellsjökull glaciers. The glaciers are in close vicinity and they created, together with the Fláajökull glacier, one piedmont foot in the years 1860-1870 (Evans, Archer, Wilson, 1999). The dating of the moraine ridges aims to provide information on the dynamics of the Fláajökull glacier front recession.

There is no clear agreement on the age of each moraine ridge of the glacier, and so it is necessary to analyse and compare data from different authors and works on Fláajökull and other glaciers.

\section{METHODS}

To obtain possibly best results several data sources were used. The lichenometric method has particularly been examined. The dating of the Fláajökull moraine ridges has already been an object of research (Dąbski,

* I would like to thank Sigfinnur Snorrason for rendering accessible his Cand Real theses, Professor Adam Kotarba for consultation on lichenometry and Professor Elżbieta MycielskaDowgiałło for useful comments. I wish to express my gratitude to Kristján Jónasson from Icelandic Institute of Natural History for the permission to conduct the research and to all who helped in the field work. 


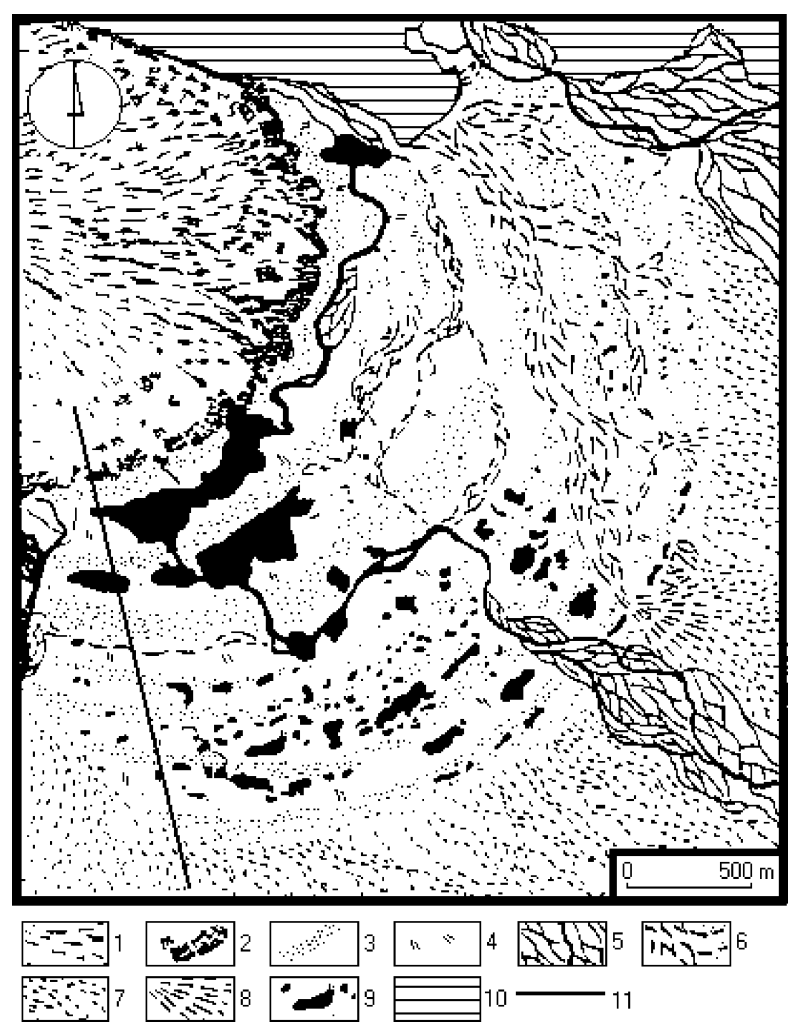

Fig. 1. Geomorphological sketch of the Fláajökull marginal zone based on aerial photograph from 1989 with analysed profile. 1 - ice surface, 2 - ice surface covered with moraine material, 3 - frontal moraine ridge, 4 - bottom moraine, 5 - beds of the current proglacial outflows, 6 - abandoned beds of proglacial outflows, 7 - beds of the outwash outflow, 8 - alluvial cone, 9 - lakes, 10 - outcrops of the rock bedding, 11 - profile presented in Fig. 3.

Fabiszewski, Pękalska, 1998). This article presents and examines a new approach to the problem. The data sources for the research were as follows:

- Glaciological measurements along the Hólmsárgarđ profile performed regularly since 1934 . They are provided by the Icelandic Glaciological Society and published in the Jökull periodical and on the WWW page of the National Energy Authority (ftp://ftp.os.is/pub/glaciers/variations).

- Comparison of a map on the scale of 1:50000 based on the aerial photographs taken in 1946 (American Map Service, 1949) with an aerial photograph from 1989.

- Data from glaciological measurements and historical data published by Ahlmann and Thorarinsson (1937), Thorarinsson (1943) and Denton (1975).

- Own lichenometric measurements performed in the year 2000 - details in the text. 
- Additional information concerning neighbourhood glaciers and the use of lichenometry in the region (Jaksch, 1975, Gordon, Sharp, 1983, Snorrason, 1984, Maizels, Dugmore, 1985, Thompson, Jones, 1986, Thomson, 1988, Evans, Archer, Wilson, 1999). -

- Data on climate change in Iceland (Einarsson, 1993, Gudmundsson,

\section{AGE OF THE MORAINE RIDGES}

Prior to undertaking of new lichenometric measurements one has to obtain and analyse all the available sources of information concerning the age of the substrate. Only after reviewing previous works one can assess the accuracy of the method.

The maximum position of Icelandic glaciers fronts in LIA (Little Ice Age) dates back to the years $1850-1930$ (Gudmundsson, 1997). Ahlmann and Thorarinsson (1937) and Thorarinsson (1943) point at the period $1882-1892$ as corresponding to the maximum position of the Fláajökull glacier front. The recession was to begin in 1894. The dates provided in Figure 2 are based on the studies mentioned as well as on the work of Denton (1975), Thompson,

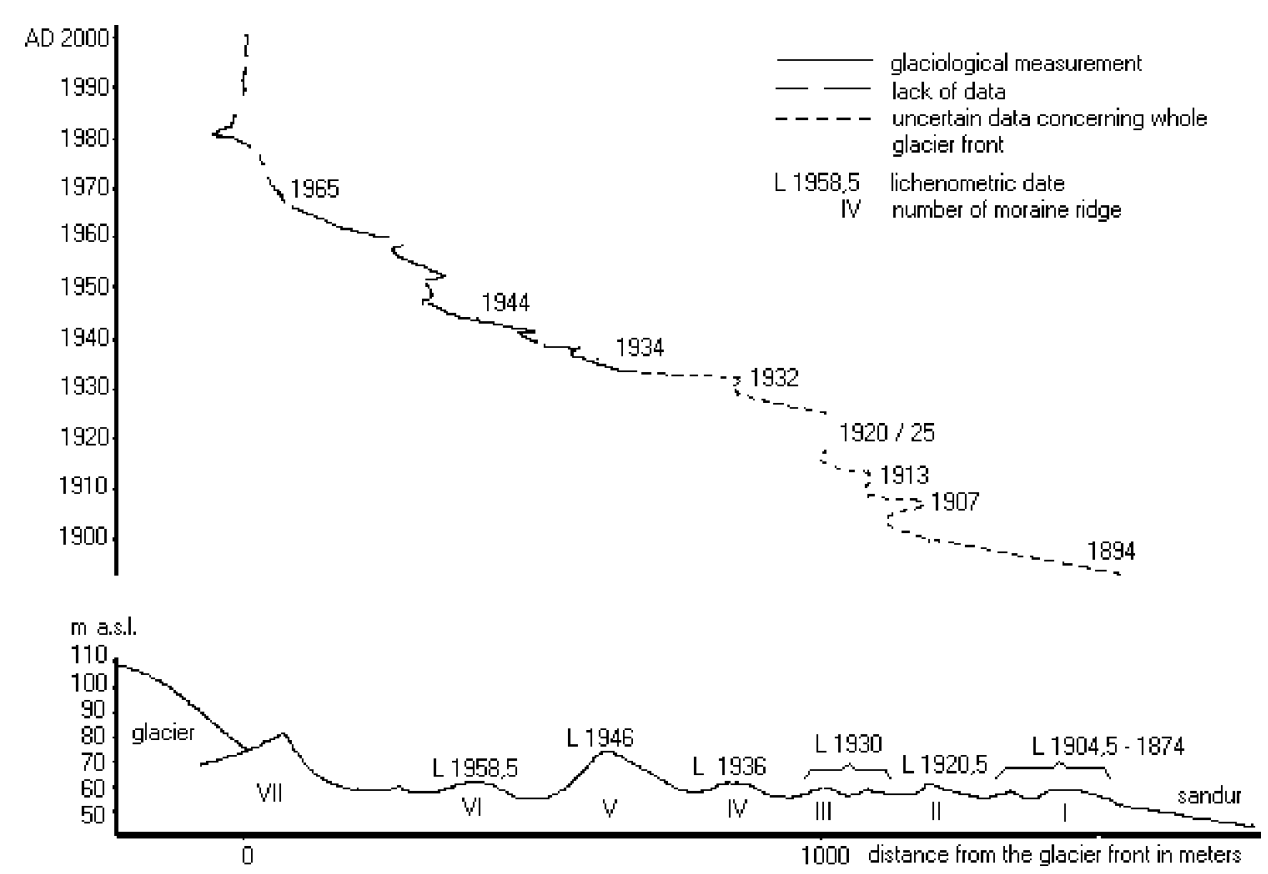

Fig. 2. Age of moraine ridges along the Hólmsárgard profile - assemblage of all data. Previous dating of the moraines (Dąbski, Fabiszewski, Pękalska, 1998) became slightly modified.

Ridges I and III are complex and therefore lichenometry was performed in the indicated zones. The cross-section drawing is based on the stereoscopic pair of aerial photographs taken in 1989. 
Jones (1986), Einarsson (1993) and Evans, Archer, Wilson (1999). It can be concluded that the following dating should be assigned to the Fláajökull moraine ridges: ridge I $-1870 / 94$, ridge II -1907 , ridge III — 1920/25.

Since 1934 regular glaciological measurements have been performed in the area (Sigurđsson, 2000, National Energy Authority WWW page). The dating of the ridges no. IV, V, VI and VII is based on the measurements referring to the aerial photograph taken in 1989, as well as to the map based on the aerial photograph from 1946 (American Map Service, 1949).

Some additional information was obtained from the talks with farmers from the area. They concerned the date of construction of the road that runs between the VI and the VII moraine ridge. It was built in the beginning of 1960s and since then it modifies the course of the Hólmsá river. The author himself has been visiting the area since 1997 and it is certain that the glacier front did not change its position until the year 2000 markedly.

The following dates for the subsequent moraine ridges can therefore be derived: ridge IV - 1932/33, V - 1934/35, VI - 1943/47, VII - 1965/2000. It becomes obvious that the Fláajökull glacier could not create high ridges in the $20^{\text {th }}$ c. Snorrason (1984) states that the ridges V, VI and VII (Fig. 2) date back to late Pleistocene. During LIA they were overridden by the glacier but their cores remained unchanged. The ridges emerged again during the $20^{\text {th }}$ century deglaciation with a new moraine cover.

\section{LICHENOMETRY}

In order to obtain additional information on the age of the surface material of moraine ridges, measurements of Rhizocarpon aggregated lichens (Innes, 1982) were collected in the year 2000. Growth rates were taken from the literature - Table 1. Ten fields along the Hólmsárgarđ profile were selected. The fields were situated on each of the moraine ridges and in the depressions between ridges, and had a shape of strips about $300 \mathrm{~m}$ long and $20 \mathrm{~m}$ wide, perpendicular to the Hólmsárgard profile. One hundred of the largest and circular thalli were selected in each field. The largest diameters (enveloping circle) were measured. Table 2 shows the average diameters of the five largest thalli among the hundred from each field.

Haines-Young (1983) proved the existence of the green-zone, the zone of relatively fast lichen growth at the base of a stoss side of moraine ridges. This was confirmed in the Fláajökull marginal zone. Therefore, only measurements done on the ridges were considered while those from the depressions were rejected. Rhizocarpon thalli appear on the youngest moraine ridge only occasionally and are very small. For this reason the VII moraine ridge was not included in the lichenometric dating.

There is no clear agreement as to the rate of the Rhizocarpon agg. lichen growth - Table 1. Lichenometric investigations in the region of Fláajökull were performed by Gordon and Sharp (1983), Snorrason (1984) and Evans, Archer, Wilson (1999). Their works were focused on the Heinabergsjökull and 
Table 1.

Growth rates and colonisation lag times of Rhizocarpon agg. provided by different studies for the Fláajökull glacier neighbourhood

\begin{tabular}{|l|c|c|}
\cline { 2 - 3 } \multicolumn{1}{c|}{} & Growth rate $(\mathrm{mm} /$ year $)$ & Colonisation lag times (years) \\
\hline Gordon et al. $(1983)$ & 0.769 & 15 \\
\hline Snorrason $(1984)$ & 0.758 & 12 \\
\hline Evans et al. $(1999)$ & 0.8 & 6.5 \\
\hline
\end{tabular}

Table 2. Average diameters of five largest lichens (enveloping circle) growing on particular moraine ridges and the age of the moraine calculated with use of the growth rate and colonisation lag after Gordon, Sharp (1983) and modification of Thompson, Jones (1986)

\begin{tabular}{|c|c|c|}
\hline Moraine ridge & $\begin{array}{c}\text { Thalli } \varnothing \text { in mm } \\
\text { (measured in year 2000) }\end{array}$ & Moraine age in years \\
\hline VI & 20.4 & 41.5 \\
\hline V & 30.0 & 54.0 \\
\hline IV & 37.6 & 64.0 \\
\hline III & 42.4 & 70.0 \\
\hline II & 47.4 & 79.5 \\
\hline I & 56.8 & 95.5 \\
\hline I* & $74^{*}$ & $126.0 *$ \\
\hline
\end{tabular}

* Average diameter of lichens for the I ridge was calculated with exclusion of one thallus, which was exceptionally large and measured $74 \mathrm{~mm}$. Such a size can be an effect of some local extraordinary good conditions. However, it can also be a remnant of an older generation developed on older material. It is stated by Thorarinsson (1943) that the glacier front fluctuated several times around its maximum position in the years $1857-1894$. This can explain one old thallus 126 years old and dating back to 1874 . Some parts of such an old moraine could be incorporated into a younger moraine ridge.

Skalafellsjökull marginal zones. The glaciers are in close vicinity and they created, together with the Fláajökull glacier, one piedmont foot in the years 1860-1870 (Evans, Archer, Wilson, 1999). Wójcik (1976) argues that Heinabergsjökull and Fláajökull were in contact until the 1930s but this does not seem to be true in the light of the new work of Evans et al. (1999). Therefore, the conditions of lichen growth in marginal zones of each of the glaciers should be nearly the same. There was also a lichenometric investigation in the marginal zone of the Fláajökull glacier performed by Jaksch (1975). He provided only the measurements of Rhizocarpon geographicum concerning the oldest moraine ridge - thalli diameters of up to $5 \mathrm{~cm}$ gave the age of 1890 (measured in 1972). There is no rate of growth and no colonisation lag time provided in his work. However, Jaksch informs about obstacles for lichen colonisation: solifluction and lack of large boulders. 


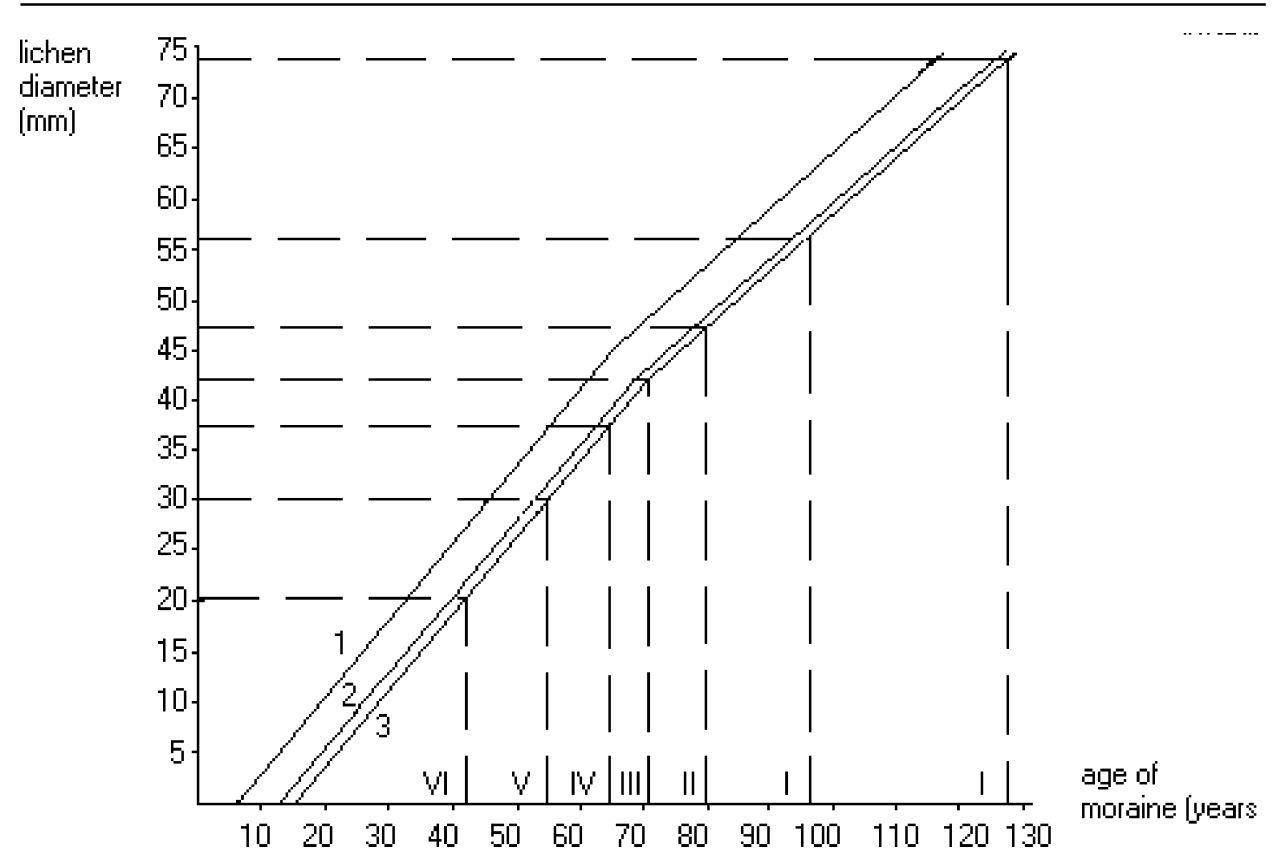

Fig. 3. The diagram showing the relation between the size of the Rhizocarpon agg. lichen and age of the surface on which it grows. It is based on data from Table 1, with modification of Thompson, Jones (1986).

I, II, III, IV, V, VI - numbers of moraine ridges. I' - see Table 2.

1 - growth rate after Evans, Archer, Wilson (1999), 2 - g.r. after Snorrason (1984),

3 - g.r. after Gordon, Sharp, (1983).

The main disagreement concerns the colonisation lag times. Gordon and Sharp (1983) use particularly long lag period - 15 years. This is due to large amounts of buried ice within the youngest moraine. Gradual melting-out of the ice causes instability of the moraine surface.

The use of the constant lichen growth rate does not seem to be proper as it is shown by Thompson and Jones (1986), who dated proglacial river terraces in south-east Iceland. They used the changing growth rates of Rhizocarpon geographicum, Rhizocarpon alpicola and Rhizocarpon rhizocarpon. The growth rate of $0.725 \mathrm{~mm} /$ year characterises lichens younger than $50-60$ years. Later, the rate slows down to $0.585 \mathrm{~mm} /$ year. It seems proper to consider such a change also in the marginal zone of the Fláajökull glacier. The growth rates given in Table 1 were modified in order to comply with the possible slow down to $0.585 \mathrm{~mm} /$ year. Figure 3 presents the obtained diagram.

Data presented in Table 2 are confronted with dates of moraine ridges inferred from previous research. Table 3 presents the disaccord between both dating. 
Table 3.

Differences between the dates based on previous research and dates based on the new lichenometric investigation

\begin{tabular}{|c|c|c|c|}
\hline Moraine ridge & $\begin{array}{c}\text { Dates based on } \\
\text { previous research }\end{array}$ & $\begin{array}{c}\text { New lichenometric } \\
\text { dates }\end{array}$ & $\begin{array}{c}\text { Differences } \\
\text { (in years) }\end{array}$ \\
\hline VI & $1943-47$ & 1958.5 & $11.5-15.5$ \\
\hline V & $1934-35$ & 1946 & $11-12$ \\
\hline IV & $1932-33$ & 1936 & $3-4$ \\
\hline III & $1920-25$ & 1930 & $5-10$ \\
\hline II & 1907 & 1920.5 & 13.5 \\
\hline I & $1870-94$ & $1874-1904.5$ & $4-10.5$ \\
\hline
\end{tabular}

\section{DISCUSSION}

The most certain dates (based on former research) are those for ridges $\mathrm{V}$ and VI because they are provided by direct glaciological measurements along the profile - Fig. 2. The new lichenometric dates are 11 to 15.5 years too young. The dates obtained for older moraines are less certain since there is no precise glaciological data.

The lichenometric dates, which are too young could result from the use of the wrong growth rates. It is possible that the rate should be lower for lichens younger than 50 years. The rate of nearly $0.8 \mathrm{~mm} /$ year may not comply with climatic fluctuations which took place in Iceland since 1950. Einarsson (1993) provides information that years 1953-1964 were characterised by relatively high temperatures, however years 1965-1990 were relatively cold, and therefore not optimal for lichen growth.

Another cause could be the underestimation of the colonisation lag times. Evans, Archer, Wilson (1999) used the colonisation lag time of 6.5 years for all the glacier marginal zones south of the Vatnajökull. This seems to be a great simplification. Snorrason (1984) used much longer lag time of 12 years. Gordon and Sharp (1983) used for the Skalafellsjökull marginal zone the lag of even 15 year. The reason for such a long lag time was the presence of buried ice within the youngest moraine ridge. Melting-out of the ice causes long instability of the surface. It is possible that the time prior to colonisation should be even greater because the Fláajökull moraines include much of buried ice.

The possible causes of obtaining too young lichenometric dates were pointed out by Maizels and Dugmore (1985). Having analysed sandur material of the Sólheimajökull glacier (southern Iceland) they notified that:

- Lichens that are measured could be already of a second generation the first one could have undergone the natural decay.

- Lichens could develop on stones that emerged to the surface some time after sedimentation due to removal of the surface layer of the material. 
- The rate of growth could not be stable due to climatic changes.

- The growth of lichens could be stopped by different processes, such as chemical and frost disintegration, frost heaving or aeolian abrasion.

- Lack of large lichens could be the result of lack of stones that are big enough to provide the best conditions for lichen development.

The dates obtained by Evans, Archer, Wilson (1999) for the Heinabergsjökull moraines, but only for the ones formed after 1946, were also too young. This is explained by the lack of large boulders on the surface. Snorrason (1984) finds similar explanation for the lower growth rate of Rhizocarpons on fine-grained surface of Fláajökull moraines, however - the lower rate is not provided. Jaksch (1975) points at active solifluction and frost weathering in the marginal zone of the Fláajökull glacier as factors limiting lichen growth.

Lichenometry as a method of age predictions is questioned by those who claim that the method has no solid foundation in biological theory. McCarthy (1999) stresses the role of microenvironments and argues that it is foolish to place great trust in age predictions based solely on the assumed normality of lichen size distributions.

\section{CONCLUSIONS}

The use of lichenometry in the dating of surface material of moraine ridges of the Fláajökull glacier should be considered under special assumptions. It can give dates 3 to 15.5 years too young because of difficulty with assessing the lichen growth rate - its value and possible fluctuations due to climatic changes. There is also a problem of assessing the colonisation lag time. It is only with other data (cartographic, historical and glaciological) that the moraines can be dated properly. Lichenometry can serve only as an additional source of information.

Lichenometry could be very helpful in dating relict forms of superficial sorting (Dabski, Gryglewicz, 1998) that occur on the Fláajökull moraines stone-filled furrows on the I and the II ridge. If it is possible to measure the statistical amount of lichens developed on such relict forms, it will be also possible to determine the minimum period of stabilisation of the forms.

Since the end of 19th c. until the year 2000 the Fláajökull glacier retreated by about $1500 \mathrm{~m}$. This was punctuated by short (usually annual) advances that occur every 3 to 7 years or less often. There are three longer advances or still-stands: $1903-1925,1948-1952,1980-2000$. Moraine ridges number I, II, III and IV were formed during the 20th c. However, the high ridges number V and VI must have been formed before the 20th c. and then only overridden without much remodelling during the LIA. Snorrason (1984) states that the ridges V, VI and even VII could have been formed during late Pleistocene.

There is a clear correlation between the main pace of the Fláajökull glacier retreat and the climatic fluctuations in the 20 th c. The periods of lower mean annual air temperature in Iceland were: 1901-1925, 1947-1952 and 1965- 
1990 (Einarsson,1993). During each of these periods the Fláajökull glacier front advanced, had a still-stand or the rate of its retreat markedly slowed down.

\section{REFERENCES}

Ahlmann, H.W., Thorarinsson, S., 1937, Previous investigations of Vatnajökull, Marginal oscillations of its Outlet-Glaciers and General Description of its Morphology, Geografiska Annaler 19 (3-4), 176-211.

Dąbski, M., Fabiszewski, B. and Pękalska, A., 1998, Marginal zone of Fláajökull (Iceland). Initial result of Research, Miscellanea Geographica 8, 47-54.

Dąbski, M., Gryglewicz, E., 1998, Selected forms of frost sorting in the marginal zone of Fláajökull (Iceland), Biuletyn Peryglacjalny 37, 19-34.

Denton, G.H., 1975, Glaciers of Iceland, [in:] W.O. Field (ed.), Mountain Glaciers of the Northern Hemisphere, vol. 2. Corps of Engineers, US Army, Hannover, 834-864.

E in ars s on, M.Á., 1993, Temperature Conditions in Iceland and the Eastern North-Atlantic Region, Based on Observations 1901-1990, Jökull 43, 1-13.

Evans, D.J.A., Archer, S., and Wilson, D.J.H., 1999, A comparison of the lichenometric and Smidt hammer dating techniques based on data from the proglacial areas of some Icelandic glaciers, Quaternary Science Reviews 18, 13-41.

Gordon, J.E., Sharp, M., 1983, Lichenometry in dating recent glacial landforms and deposits, southern Iceland, Boreas 12 (3), 191-200.

Guđmundsson, H.J., 1997, A Review of the Holocene Environmental History of Iceland, Quaternary Science Review 16, 81-92.

Ha ines-Young, R.H., 1983, Size variation of Rhizocarpon on Moraine Slopes in Southern Norway, Arctic and Alpine Research 15 (3), 295-305.

Innes, J.L., 1982, Lichenometric use of an aggregated Rhizocarpon species, Boreas 11, $53-57$.

Jaksch, K., 1975, Das Gletschervorfeld des Solheimajokull, Jökull 25, 34-38.

Maizels, J.K., D ug more, A.J., 1985, Lichenometric dating and Tephrochronology of Sandur Deposits, Sólheimajökull Area, southern Iceland, Jökull 35, 69-78.

McCarthy, D.P., 1999 A biological basis for lichenometry ? Journal of Biogeography 26, $379-386$.

Sigur đsson, O., 2000, Jöklabreytingar 1930-1960, 1960-1990 og 1996-1997, Jökull 48.

Smolska, E., Szw arczewski, P., Giriat, D., Borkowski, K., 1998, Texture characterization of the contemporary coarse clastic outwash sediments of Fláajökull and Falljökull in south-eastern Iceland, Miscellanea Geographica 8, 55-65.

Snorrason, S., 1984, Mýrarjöklar og Vatnsdalur. Cand Real theses, University of Oslo, $115 \mathrm{pp}$.

Thom ps on, A., 1988, Historical Development of the Proglacial Landforms of Svínafellsjökull and Skaftafellsjökull, Southeast Iceland, Jökull 38, 17-30.

Thompson, A., Jones, A., 1986, Rates and causes of proglacial river terrace formation in southeast Iceland: an application of lichenometric dating techniques, Boreas 15 (3), $231-246$.

Thorarinsson, S. , 1943, Oscillations of the Icelandic Glaciers in the last 250 years. Vatnajökull, Scientific Results of the Swedish-Icelandic Investigation 1937, 38-39, Geografiska Annaler 25 (1-2).

Wójcik, G., 1976, Zagadnienia klimatologiczne i glacjologiczne Islandii [Climatologic and glaciologic issues in Iceland; in Polish], Rozprawy Uniwersytetu Mikołaja Kopernika, Toruń, $226 \mathrm{pp}$. 